\title{
Genetic and morphological characterization of Rivularia and Calothrix (Nostocales, Cyanobacteria) from running water
}

\author{
Correspondence \\ Pilar Mateo \\ pilar.mateo@uam.es
}

\author{
Esther Berrendero, Elvira Perona and Pilar Mateo \\ Departamento de Biología, Facultad de Ciencias, Universidad Autónoma de Madrid, 28049 Madrid,
Spain
}

\begin{abstract}
In this study, a polyphasic approach was adopted to investigate natural freshwater (river and stream) samples of Rivularia colonies and isolated strains of cyanobacteria with a high degree of trichome tapering (genera Rivularia and Calothrix). Analysis of the phycocyanin (PC) operon and the intervening intergenic spacer ( $c p c B A-I G S)$ and 16S rRNA gene sequences were used for genetic characterization. In addition, a molecular fingerprinting method, temperature-gradient gel electrophoresis, which allows sequence-dependent separation of PCR products, was used to assess genotypic diversity in environmental samples and isolated strains. The results showed a high variability of the PC-IGS among the genotypes that was not associated with the morphologies observed. This study underlines the importance of choosing a low-nutrient-content culture medium, especially one with a low phosphorus concentration, for studying typical morphological features of Rivularia for taxonomic purposes. Molecular fingerprinting methods and morphological analyses confirmed the diversity in Rivularia colonial structure and trichome features corresponding to genetic diversity within a single colony. Phylogenetic analysis of сpсBA-IGS was largely consistent with that obtained from 16S rRNA gene sequence analysis and confirmed the high level of divergence between genotypes. The sequences of Rivularia and Calothrix from this study and database sequences showed great heterogeneity and were clearly not monophyletic. The results of this genetic and morphological study of field samples and fresh isolates indicated that the current classification of these genera needs to be revised.
\end{abstract}

\section{INTRODUCTION}

Heterocystous cyanobacteria correspond to a monophyletic lineage (Wilmotte \& Herdman, 2001) that contains the orders Nostocales and Stigonematales (subsections IV and V) (Rippka et al., 1979; Castenholz, 2001). The genera Rivularia and Calothrix belong to the order Nostocales and the family Rivulariaceae according to traditional classification (Geitler, 1932; Komárek \& Anagnostidis, 1989; Whitton, 2002) and to subsection IV by bacteriological classification (Rippka et al., 2001a). The Rivulariaceae are among the most morphologically complex cyanobacteria (Whitton, 1987). They are characterized by tapered trichomes, apart from short phases of hormogonium

Abbreviations: $c p c B A-I G S$, phycocyanin operon intergenic spacer; $\mathrm{NJ}$, neighbour-joining; MP, maximum-parsimony; PC, phycocyanin; TGGE, temperature-gradient gel electrophoresis.

The GenBank/EMBL/DDBJ accession numbers for the 16S rRNA and cPcBA-IGS gene sequences determined in this study are EU009142EU009154 and EU009155-EU009172, respectively.

A figure showing a multiple sequence alignment of PC-IGS of cyanobacterial genera is available as supplementary material with the online version of this paper. formation. The mature trichome has a terminal heterocyst, although some species also have intercalary heterocysts, and cell division is largely localized to a region near the heterocyst (Whitton, 2002). Traditional taxonomy (Geitler, 1932) included 12 genera, some of which are widespread and others that have rarely been recorded (Whitton, 1987). Thus, Calothrix, Rivularia and Gloeotrichia can be considered the most representative genera of this group and are the most thoroughly studied. The genus Rivularia Agardh is easily distinguishable in the field by its characteristic development as gelatinous, hemispherical or subspherical colonies containing a large number of filaments, arranged radially or sometimes parallel to each other in part of the colony (Geitler, 1932; Komárek \& Anagnostidis, 1989; Whitton, 2002). However, isolates from natural colonies identified as Rivularia often do not produce gelatinous colonies in culture and as such are indistinguishable from the genus Calothrix. Thus, Rippka et al. (1979) included in the genus Calothrix all heterocystous cyanobacteria with a low or high degree of tapering, irrespective of their ecology, on the grounds that colony appearance observed in feral samples was a taxonomic trait of dubious value (Rippka et al., 2001c). 
However, Komárek \& Anagnostidis (1989) pointed out that the genus Rivularia differs also by other morphological features such as the sheath morphology, which has repercussions for the development of meristematic zones where divided trichomes and young filaments persist within common old sheaths. DNA-DNA hybridization studies (Lachance, 1981) also showed that freshwater and soil isolates of Calothrix were unrelated to the marine representatives. Consequently, Rippka et al. (2001b, c) assigned the marine members to the genus Rivularia. In a recent study (Sihvonen et al., 2007), analysis of sequences of cyanobacterial cultures and environmental samples belonging to the genera Calothrix, Rivularia and Gloeotrichia from the Baltic Sea revealed a high level of genetic diversity and overlapping morphologies among phylogenetic groups. The authors pointed out that the Calothrix morphotype was also a highly diverse group genetically, and one in need of revision (Sihvonen et al., 2007). Therefore, it remains a difficult task to establish an accurate taxonomy of traditional Rivulariaceae.

Many authors have stressed that traditional morphological characteristics must be integrated with genetic characterization (polyphasic approach), and interpreted both within and between taxa, to resolve taxonomic issues (Wilmotte, 1994; Komárek \& Kaštovský, 2003; Garcia-Pichel et al., 2001; Castenholz \& Norris, 2005; Taton et al., 2006). Molecular genetic approaches have been developed that have the potential to resolve relationships between closely related cyanobacteria. The sequences of the rRNA genes have been used successfully to aid morphological taxonomy. However, at the intrageneric level the rRNA (16S rRNA) gene sequences have demonstrated little clearly interpretable variation among several strains of cyanobacteria (Fox et al., 1992; Moore et al., 1998). An alternative to the use of conserved 16S rRNA genes is to examine intergenic spacer regions which usually show considerably more variation, for example the intervening intergenic spacer of the c-phycocyanin (PC) genes $c p c A$ and $c p c B$ (cpcBA-IGS) (Neilan et al., 1995; Bolch et al., 1996).

In this work we have adopted a polyphasic approach to examine natural freshwater (rivers or streams) samples of Rivularia colonies and isolated strains of cyanobacteria with a high degree of tapering (genera Rivularia and Calothrix). We examined the samples by microscopy and analysed the 16S rRNA gene sequences and the PC operon and the intervening intergenic spacer ( $c p c B A-I G S)$. In addition, a molecular fingerprinting method, temperaturegradient gel electrophoresis (TGGE), which allows sequence-dependent separation of PCR products (Muyzer \& Smalla, 1998), was used to assess genotypic diversity in environmental samples and isolated strains.

\section{METHODS}

Sampling. The locations of sampling sites from which samples were collected are shown in Table 1. The Muga, Matarraña, Endrinales, Blanco and Alharabe rivers are located in the Mediterranean region of Spain. These rivers are characterized by highly calcareous waters. Red

Table 1. Isolated strains and field Rivularia colonies examined in this study

\begin{tabular}{|lcl|}
\hline Sample & Culture collection no. ${ }^{*}$ & \multicolumn{1}{c|}{ Geographical origin } \\
\hline Natural environment samples & & \\
Rivularia colonies Alharabe & - & Alharabe river, Murcia, south-east Spain \\
Rivularia colonies Blanco & - & Blanco river, Teruel, east Spain \\
Rivularia colonies Endrinales & - & Endrinales river, Albacete, south-east Spain \\
Rivularia colonies Matarraña & - & Matarrana river, Teruel, east Spain \\
Rivularia colonies Muga & - & Muga river, Girona, north-east Spain \\
Rivularia colonies Red & - & Red Sike, Upper Teesdale, northern England, UK \\
Isolated strains & & \\
BL1 & UAM 346 & Blanco river, Teruel, east Spain \\
BL2 & UAM 347 & Blanco river, Teruel, east Spain \\
E1 & UAM 302 & Endrinales river, Albacete, south-east Spain \\
E7 & UAM 313 & Endrinales river, Albacete, south-east Spain \\
E17 & UAM 358 & Endrinales river, Albacete, south-east Spain \\
MA8 & UAM 355 & Matarraña river, Teruel, east Spain \\
MA14 $\dagger$ & - & Matarraña river, Teruel, east Spain \\
MU15 & UAM 369 & Muga river, Girona, north-east Spain \\
MU24 & UAM 305 & Muga river, Girona, north-east Spain \\
MU27 & UAM 315 & Muga river, Girona, north-east Spain \\
MU28 & UAM 341 & Muga river, Girona, north-east Spain \\
MU41 & UAM 370 & Muga river, Girona, north-east Spain \\
TJ12 & UAM 372 & Tejada stream, Madrid, central Spain \\
\hline
\end{tabular}

*UAM, UAM Culture Collection, Universidad Autónoma de Madrid, Spain.

$†$ Strain MA14 was only cultivable for a few months. 
Sike is a stream in the Upper Teesdale National Nature Reserve, an upland area of northern England, which is also highly calcareous. However, Tejada stream, located in central Spain, near Madrid, flows through siliceous substrates.

Rivularia colonies were collected from calcareous rivers, where they were dominant. In addition, several cobbles or pebbles were collected from a submerged part of the riverbank. The epilithon was removed from these stones by brushing and was then resuspended in culture medium. Aliquots were used for cyanobacterial culturing on Petri dishes $(1.5 \%$ agar $)$ in order to isolate species. The cells were spread out in the nitrogen-free medium described by Mateo et al. (1986), Allen and Arnon's medium (AA) (Allen \& Arnon, 1955), BG11 (Rippka et al., 1979) and a modification of CHU No. 10 (CHU10) medium (Chu, 1942) to give a final phosphorus concentration of $0.2 \mathrm{mg}^{-1}$. This enrichment was allowed to grow, and was examined under the microscope to distinguish different morphotypes. Cultures were obtained by picking material from the edge of discrete colonies that had been growing for approximately 4 weeks on solid medium. Clonal isolates were obtained by subculturing a single filament originating from the same colony twice (Rippka et al., 1979). Cultures were grown in light:dark periods of $16: 8 \mathrm{~h}$ at a temperature of $18{ }^{\circ} \mathrm{C}$. The intensity of light during the light period was $20 \mu \mathrm{mol}$ photon $\mathrm{m}^{-2} \mathrm{~s}^{-1}$. The strains (Table 1) were named after the river or stream from which they originated.

Morphological characterization. Morphological observations of environmental Rivularia colonies and isolated strains were made using a dissecting microscope (Leica; Leica Microsystems) and an Olympus BH2-RFCA photomicroscope equipped with phase-contrast and video camera systems (Leica DC Camera; Leica Microsystems). The key features taken into consideration for the identification and differentiation of natural samples and isolates were: the environment (freshwater or marine and brackish water), the colony or thallus (hemispherical colonies, solitary trichomes or their groups), calcification (abundant, moderate or slight, absent), texture (hard, soft or gelatinous), section of colony (marked zonation, little or no zonation), the filaments (arrangement of trichomes, heteropolarity, hairs, width of trichomes), morphology of sheaths (colour and lamellations), type and frequency of false branching and development of falsely branched filaments (divided trichomes and young filaments within common old sheaths or not, thus secondary trichomes remaining or not remaining in the 'mother' sheath), according to traditional criteria (Geitler, 1932; Whitton, 1987, 2002; Komárek \& Anagnostidis, 1989).

Isolation of genomic DNA. Total genomic DNA from isolated cultures or frozen field samples was extracted following a modification of a technique for isolating DNA from fresh plant tissue, using cetyltrimethylammonium bromide (CTAB) (Doyle \& Doyle, 1990). Cells were harvested by centrifugation after the addition of about $150 \mu \mathrm{l}$ of sterile glass beads $(212-300 \mu \mathrm{m}$; Sigma) and resuspended in $400 \mu \mathrm{l}$ extraction buffer [100 mM Tris/ $\mathrm{HCl}, \mathrm{pH}$ 8.0, $20 \mathrm{mM}$ EDTA, $2.5 \%(\mathrm{w} / \mathrm{v})$ CTAB, $1.4 \mathrm{M} \mathrm{NaCl}, 0.2 \%(\mathrm{v} / \mathrm{v})$ 2-mercaptoethanol]. Samples were frozen in liquid nitrogen and then homogenized in extraction buffer using a hand-operated homogenizer (Bosch, CSB$850-2 \mathrm{RET})$. Subsequently, they were incubated at $60{ }^{\circ} \mathrm{C}$ for $30 \mathrm{~min}$, followed by two extractions with chloroform. DNA-containing phases were placed in new tubes and an equal volume of 2-propanol was added. The samples were centrifuged at $12000 \mathrm{~g}$ for $5 \mathrm{~min}$. The pellet was resuspended in $400 \mu \mathrm{l}$ sterile water and DNA was precipitated again by addition of 0.1 volumes of $3 \mathrm{M}$ sodium acetate and two volumes of ethanol before being stored at $-20{ }^{\circ} \mathrm{C}$ in $15 \mu \mathrm{l}$ sterile water.

PCR amplification and cloning of the PC-IGS region: design of specific primers. PCR amplifications were performed with a
Perkin-Elmer GeneAmp 2400 PCR system. The reaction volume was $25 \mu \mathrm{l}$ and contained $6 \mu$ l genomic DNA, $10 \mathrm{pmol}$ of each primer, $200 \mu \mathrm{M}$ dNTP, $1 \mu \mathrm{g}$ BSA, $1.5 \mathrm{mM} \mathrm{MgCl}_{2}, 2.5 \mu \mathrm{l} 10 \times$ polymerase buffer, $5 \mu \mathrm{l} 5 \times$ Eppendorf Taqmaster PCR-enhancer and $0.75 \mathrm{U}$ Ultratools DNA polymerase (Biotools). Primers PC $\beta$ (forward primer) and $\mathrm{PC} \alpha$ (reverse primer) were adopted initially using the conditions described by Neilan et al. (1995). As amplification of the DNA was not successful, and not enough DNA for direct sequencing was obtained, PCR products were cloned using a Qiagen PCR Cloning $^{\text {plus }}$ kit. Recombinant clones carrying the correct-sized insert were sequenced in both strands. Subsequently, the primers RivF ( $5^{\prime}-$ TGGAAATCATCTTGCGCTATGT- $3^{\prime}$ ) and RivR (5'-CACCAGCAACTAAACAGTA- $3^{\prime}$ ) were deduced from the alignment of the sequences obtained and were used to amplify this region. PCR consisted of initial denaturation at $94{ }^{\circ} \mathrm{C}$ for $5 \mathrm{~min}, 30$ cycles at $94{ }^{\circ} \mathrm{C}$ for $1 \mathrm{~min}, 52{ }^{\circ} \mathrm{C}$ for $1 \mathrm{~min}$ and $72{ }^{\circ} \mathrm{C}$ for $1 \mathrm{~min}$, followed by a final extension at $72{ }^{\circ} \mathrm{C}$ for $10 \mathrm{~min}$. The concentration of the amplified products was checked on a $1.5 \%$ agarose gel and the products were purified using the Real Clean Spin kit (Real).

PCR amplification of the 16S rRNA gene. To amplify the 16S rRNA gene segments, two sets of cyanobacteria-specific primers were used, as described by Nübel et al. (1997) and Wilmotte et al. (2002). This produced fragments of about 700 and $1400 \mathrm{bp}$, respectively. The reaction conditions used were those described by Nübel et al. (1997). The PCR product was quantified as described above for the PC-IGS region.

Sequencing. DNA sequencing was performed and analysed by using the chain-termination method with the DyeDeoxy terminator cycle sequencing kit protocol, following the manufacturer's instructions (Applied Biosystems). The sequences were obtained for both strands independently.

TGGE analysis of PC-IGS PCR products. TGGE Maxi System (Biometra) was used for sequence-specific separation of PCR products. A 23-nucleotide GC-rich sequence was attached to the 5'end of the forward primer to improve the detection of sequence variation in the amplified DNA fragments by subsequent TGGE (Sheffield et al., 1989). Electrophoresis was performed by loading $6 \mu \mathrm{l}$ of PCR product in a gel containing $5 \%$ acrylamide/bisacrylamide, $8 \mathrm{M}$ urea, $2 \%$ glycerol, $20 \%$ formamide and $1 \%$ TAE, as described previously (Rodríguez et al., 2007), with a gradient ranging from 40 to $51{ }^{\circ} \mathrm{C}$. The gels were then stained following a routine silver-staining protocol (Sanguinetti et al., 1994) and photographed using a Nikon Coolpix 995 digital camera.

Analysis of sequence data. Nucleotide sequences obtained from DNA sequencing were compared with sequence information available in the National Center for Biotechnology Information database using BLAST (http://www.ncbi.nlm.nih.gov/BLAST). Multiple-sequence alignment was done with all partial and complete sequences using the CLUSTAL_X package (Thompson et al., 1997). Alignments were corrected manually using GeneDoc version 2.6.002 (Nicholas \& Nicholas, 1997). Trees based on the cpcBA-IGS and 16S rRNA gene were constructed using the neighbour-joining $(\mathrm{NJ})$ and maximumparsimony (MP) algorithms (Saitou \& Nei, 1987) in MEGA 3.1 (Kumar et al., 2004). Distances for the NJ tree were estimated by using the algorithm of Tajima \& Nei (1984) and nucleotide positions containing gaps and missing data were considered. The parameters (base frequencies, substitution rate matrix of types and shape of gamma distribution) were estimated from the data. Bootstrap analysis of 1000 replications was performed for each consensus tree (Felsenstein, 1985). Similar clustering was obtained with the NJ and MP algorithms, so we have chosen to represent the PC sequence relationships with the neighbour-joining tree (696 bp). In the case of the ribosomal operon, complete sequences (Escherichia coli 
positions 27-1494) were determined (on both strands) for at least one representative genotype. However, because we also generated $16 \mathrm{~S}$ rRNA gene fragments from about 700 to $1400 \mathrm{bp}$ (except one of about $400 \mathrm{bp}$ ), and there are many short sequences in GenBank/ EMBL/DDBJ, we constructed several trees with partial as well as complete sequences. Since similar clustering was obtained by using both NJ and MP methods with our complete and database complete sequences, we represented the NJ tree (461 bp, E. coli positions 362823 ) in order to include genetically closely related but partial Calothrix sequences from GenBank/EMBL/DDBJ.

\section{RESULTS AND DISCUSSION}

\section{Morphological observations and cpcBA-IGS sequence analysis}

Field Rivularia colonies and fresh rivulariacean-type isolates from calcareous rivers (Table 1) were evaluated macroscopically and microscopically to characterize them morphologically (Fig. 1). Some field-collected Rivularia colonies could be identified according to traditional morphological criteria (Geitler, 1932; Komárek \& Anagnostidis, 1989; Whitton, 2002) as Rivularia biasolettiana [Ag.] Born. et Flah., showing the typical characteristics of this taxon, such as hemispherical colonies, colour from blue-green, dark olive-green to golden-brown, with calcite crystals deposited inside mucilage, but the extent varying markedly, sheaths wide, lamellated, splayed out at the apical end, some yellow-brown, though usually very pale ones, present (Fig. 1a-c). Other colonies that were highly calcified and whose sections showed obvious zonation were identified as Rivularia haematites [Men.] Born. et Flah. (Fig. 1d-f). Similar occurrence of both types of Rivularia on rocks in calcareous springs and streams has been described previously (Whitton, 2002), and are dominant in the majority of the Spanish rivers studied (Aboal et al., 2002, 2005). However, when the rivulariacean-type strains isolated from these calcareous rivers (Table 1), where Rivularia was dominant, were cultured under laboratory conditions and examined morphologically, all of them were very similar phenotypically (Fig. $1 \mathrm{~g}, \mathrm{~h}$ ). The strains all showed Calothrix-like morphological characteristics and did not exhibit features typical of the genus Rivularia. Previous reports featured isolates from natural colonies that, although they were identified as Rivularia, did not produce gelatinous colonies in culture and therefore were indistinguishable from Calothrix (Rippka et al., 1979).

In order to distinguish between related isolates and to compare them with natural environment samples the PC operon was used as a molecular marker. The $c p c B A$-IGS genetic analysis showed that all the sequences of environmental Rivularia colonies and rivulariacean-type isolates from calcareous rivers (confirmed on both strands) fell into one of three distinct classes of genotype (Table 2). These genotypes were designated PC-IGS type I, type II and type III. All three genotypes shared the same length for coding regions, but differed in the IGS region, so that the length of PC fragment varied from 688 to $696 \mathrm{nt}$ (Table 2).
Sequences within a genotype class were identical or had a high percentage of similarity to each other. Alignment of the sequences revealed $100 \%$ similarity of some isolated strains with the sequences found in some field Rivularia colonies, suggesting that they might belong to the genus Rivularia (data not shown). When considered by genotype, fragments exhibited a maximum pairwise divergence of $1 \%$ in type I, $0.3 \%$ in type II and $0.6 \%$ in type III for the calcareous rivulariacean-type. When we analysed a Calothrix-like strain (TJ12) isolated from the siliceous Tejada stream, where Rivularia is unable to grow, we found that the sequence clearly fell into the genotype II class although it showed more variability (2.7\%). Genotype I was found in natural Rivularia colonies from the Endrinales and Matarraña rivers, and in the isolated strains BL1, BL2, E1, E7, MA8, MU15 and MU24. Genotype II was found only in isolated cultures E17, MU27, MU28, MU41 and TJ12. Genotype III was found in natural Rivularia colonies from Muga river, Alharabe river and Red Sike, and in strain MA14. This strain could only be maintained in culture for a few months and, therefore, although PC operon sequence analysis was performed when the strain was first isolated, no subsequent analyses could be made.

Sequence divergence between genotype types ranged from 13.7 to $31.9 \%$ (Table 3 ). Sequence type III was the most divergent, with very similar percentages of nucleotide substitution along the entire fragment, and a variation of $20-30 \%$ in the coding regions, and greater than $60 \%$ in IGS. Differences between sequences of genotypes I and II were $7.0 \%$ in $c p c B, 38.6 \%$ in IGS and $11.7 \%$ in $c p c A$. (Table 3). Multiple alignment of the sequences of this IGS region of samples from this study and database entries indicate that the nucleotide sequence is highly conserved within each genotype, but clearly differs among them. This information is available as Supplementary Fig. S1 in IJSEM Online. Thus, the large sequence divergence in the PC-IGS among the genotypes found indicated a clear taxonomic separation. Sequence analysis within the genera Microcystis and Nodularia revealed intrageneric sequence variation across the $c p c B A$-IGS of 6.4 and $6.7 \%$, respectively. The percentages of nucleotide substitutions were $6.9 \%$ for $c p c B$, $13.7 \%$ for $c p c A$ and $7.6 \%$ for IGS for the genus Microcystis (Bittencourt-Oliveira et al., 2001), and 8.2 and $8.4 \%$ for the coding regions and $11.7 \%$ for IGS for the genus Nodularia (Bolch et al., 1999). Manen \& Falquet (2002) found $5 \%$ variable positions within the PC-IGS locus in the genus Arthrospira, and Barker et al. (2000) recorded a value of $5.4 \%$ in Aphanizomenon. In contrast, Teneva et al. (2005) showed a greater divergence $(16.5 \%)$ in Phormidium. Robertson et al. (2001) also found a high level of sequence divergence in the genus Synechococcus. However, based on sequences from a large number of isolates for both the 16S rRNA gene and $c p c B A-\mathrm{IGS}$, the authors suggested that the genus Synechococcus should be revised extensively. Thus, the high degree of variability among the three genotypes appeared to indicate that they belong to different genera. 

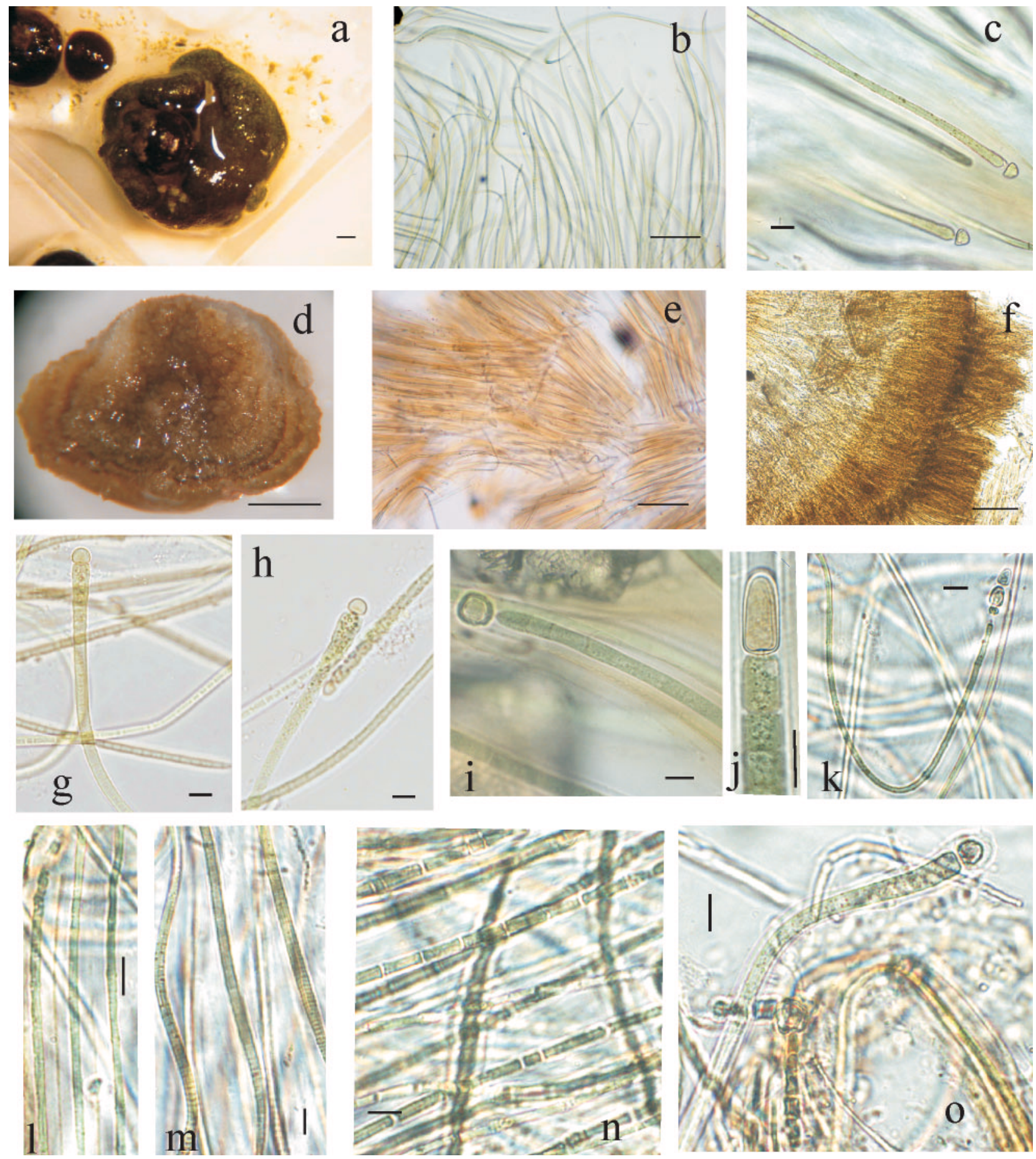

Fig. 1. Microphotographs of field Rivularia colonies and isolated strains showing morphological variability. (a-c) Rivularia colony from Alharabe river, R. biasolettiana type; $(\mathrm{d}-\mathrm{f})$ Rivularia colony from Endrinales river, R. haematites type; ( $\mathrm{g}$ ) isolated strain MU27; $(h)$ isolated strain MU24; ( $i$ and j) different trichomes found in a single Rivularia colony from Red Sike; ( $k-n$ ) different trichomes found in a single Rivularia colony from Matarraña river; (o) Calothrix filament found in a Rivularia colony from Muga river. Bars, $1 \mathrm{~mm}(\mathrm{a}, \mathrm{d}), 100 \mu \mathrm{m}$ (b, e and f) and $10 \mu \mathrm{m}$ (c, g-o).

However, this high variability of the PC-IGS among the three genotypes was not associated with the morphology observed, as all isolates had typical Calothrix-like features.
In order to study the morphological variability of our rivulariacean-type isolates in detail and, as the initial isolates were obtained using nutrient-rich media, the 
Table 2. Summary of the length of the $c p c B A-I G S$ locus of genotypes I, II and III, percentage similarity, and environmental colonies or isolated cultures in which these genotypes were found

\begin{tabular}{|c|c|c|c|c|c|c|}
\hline Genotype & $\begin{array}{c}\text { PC } \\
\text { fragment }(n t)\end{array}$ & $\operatorname{cpcB}(\mathrm{nt})$ & $\operatorname{cpcA}(\mathrm{nt})$ & IGS (nt) & $\begin{array}{l}\text { Percentage } \\
\text { similarity }\end{array}$ & Strains/colonies \\
\hline I & 688 & 283 & 314 & 91 & 99-100 & $\begin{array}{l}\text { Rivularia Endrinales } \\
\text { Rivularia Matarraña } \\
\text { BL1, BL2 } \\
\text { E1, E7 } \\
\text { MA8 } \\
\text { MU15, MU24 }\end{array}$ \\
\hline II & 696 & 283 & 314 & 99 & $97.3-100$ & $\begin{array}{l}\text { E17 } \\
\text { MU27, MU28, MU41 } \\
\text { TJ12 }\end{array}$ \\
\hline III & 693 & 283 & 314 & 96 & $99.4-100$ & $\begin{array}{l}\text { Rivularia Muga } \\
\text { Rivularia Alharabe } \\
\text { Rivularia } \text { Red } \\
\text { MA14 }\end{array}$ \\
\hline
\end{tabular}

cultures were transferred to a medium with a low level of nutrients that more closely approximated the characteristics of the rivers with Rivularia colonies (liquid CHU10modified medium - see Methods). Fig. 2 shows that isolated strains that presented as genotype I were able to adopt Rivularia-like morphological characteristics when the culture conditions were changed, including secondary trichomes remaining in the 'mother' sheath (Fig. 2a), lamellated sheath (Fig. 2b) and confluent trichomes (Fig. 2c, d).

However, isolated strains that presented as genotype II maintained Calothrix-like morphological characteristics when the culture conditions were changed (Fig. 2e, f). In addition, colonies of strains corresponding to genotype I tended to be spherical whereas strains corresponding to genotype II formed groups of filaments or irregularly shaped trichome bundles in liquid culture (Fig. 2g, h).

A more detailed study was carried out to assess the influence of the medium on morphological variability of Rivularia on agar plates. Three different types of media were selected in order to have a wide range of nutrient concentrations: CHU10-modified was selected as a very low nutrient and salt content medium $(0.2 \mathrm{mg}$ phosphorus $\left.\mathrm{l}^{-1}\right), \mathrm{BG} 11_{0}\left(\sim 5 \mathrm{mg}\right.$ phosphorus $\left.\mathrm{l}^{-1}\right)$ and AA as a very high

Table 3. Variable substitutions determined in the nucleotide sequences of genotypes I, II and III

Values given are percentage divergence.

\begin{tabular}{|lcccl|}
\hline Genotype & PC fragment & $\boldsymbol{c p c} \boldsymbol{B}$ & $\boldsymbol{c p c} \boldsymbol{A}$ & IGS \\
\hline I and II & 13.7 & 7 & 11.7 & 38.6 \\
I and III & 31.5 & 21.9 & 30.5 & 62.2 \\
II and III & 31.9 & 21.2 & 30.5 & 66 \\
\hline
\end{tabular}
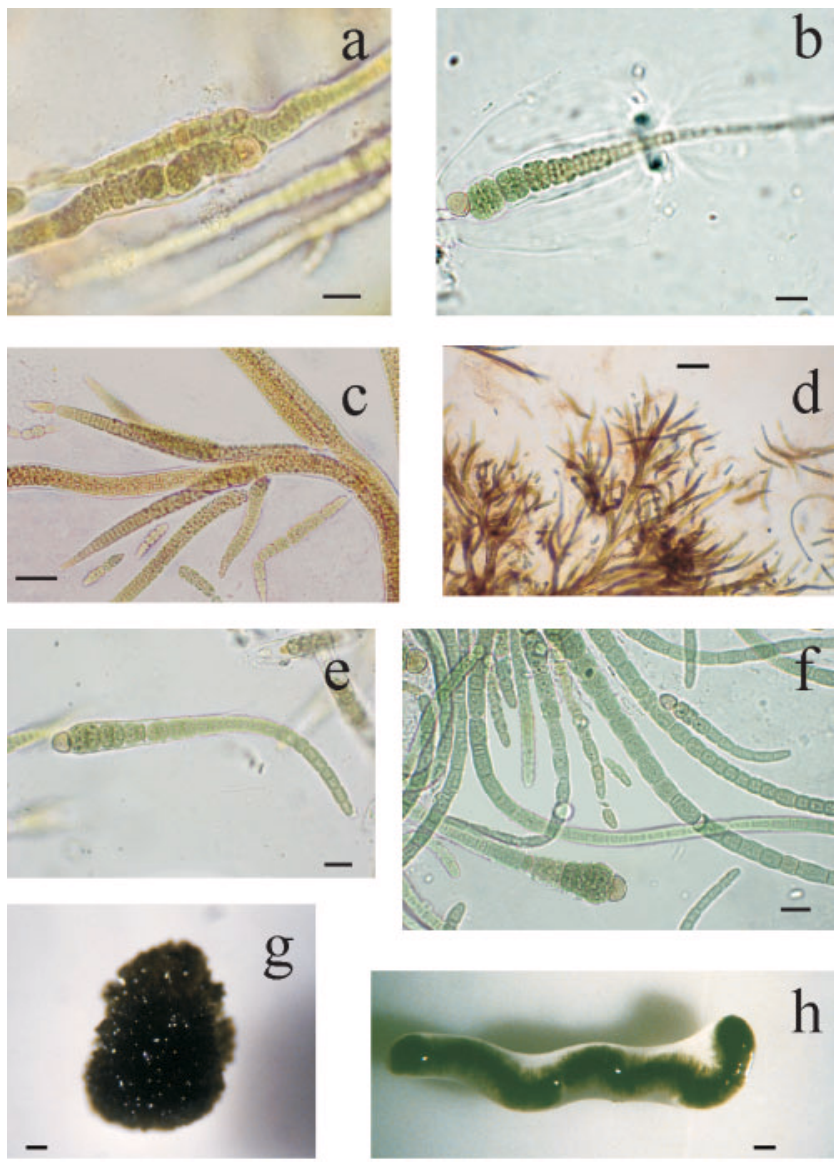

Fig. 2. Morphology of representatives of isolated strains cultured in the low-nutrient content $\mathrm{CHU10-modified} \mathrm{medium} \mathrm{(liquid).} \mathrm{(a)}$ Strain E1; (b) strain MU24; (c and d) strain MU15; (e) strain E17; (f) strain MU41; (g) strain MU24; and (h) strain MU27. Bars, $1 \mathrm{~mm}$ ( $\mathrm{g}$ and $\mathrm{h}$ ), $100 \mu \mathrm{m}(\mathrm{d})$ and $10 \mu \mathrm{m}(\mathrm{a}-\mathrm{c}$, e and $\mathrm{f}$ ). 


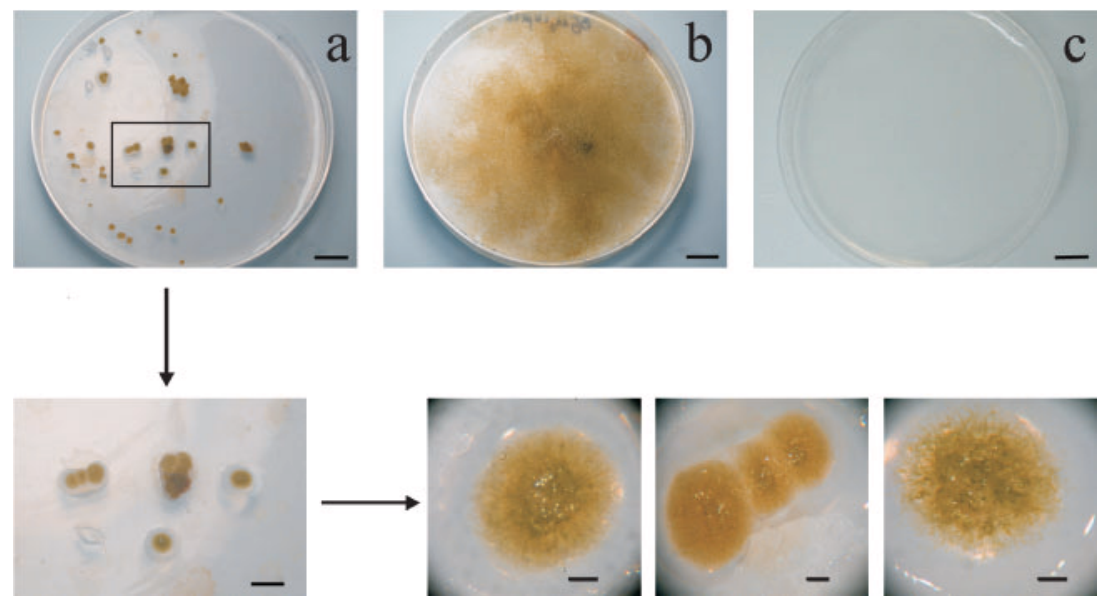

Fig. 3. Effect of different culture media on Rivularia colonies on agar plates. (a) CHU10modified medium; (b) BG11。 medium; and (c) AA medium. Bars, $10 \mathrm{~mm}(\mathrm{a}-\mathrm{c})$; insets: $5 \mathrm{~mm}$ (left) and $500 \mu \mathrm{m}$ (three right panels).

nutrient concentration medium ( $\sim 60 \mathrm{mg}$ phosphorus $\left.\mathrm{l}^{-1}\right)$. When a single colony of Rivularia was homogenized and aliquots were spread on agar plates of these media, differences in growth and morphology became apparent (Fig. 3). In CHU10 low-phosphorus medium, typical hemispherical colonies grew after about 2 months (Fig. 3a). In $B G 11_{0}$, filaments were spread all over the surface, similar to Calothrix cultures (Fig. 3b). Finally, Rivularia was unable to grow in the AA medium with very high nutrient concentrations (Fig. 3c).

The importance of the choice of laboratory culture medium has been emphasized for a long time (Whitton, 1992; Whitton \& Potts, 2000). Whitton (2002) pointed out that, whereas most researchers are aware of the need to grow an organism in nitrogen-free medium if it is a nitrogen-fixer, organisms have been grown much less frequently under phosphorus limitation and only very rarely so in taxonomic studies, and that major taxonomic studies and routine subculturing of culture collection strains have often been conducted in a medium containing too much phosphate. This means that morphological features that are influenced by phosphorus limitation are never seen and, in the case of some strains in culture collections, may have been lost genetically (Whitton, 2002). Many authors agree that the extreme phenotypic flexibility of many species of cyanobacteria in culture produces atypical or anomalous morphologies that are different from those typically found in nature (Golubic, 1979; Komárek \& Anagnostidis, 1999; Pomati et al., 2000). It has been suggested that the low correlation of phenotypic features and genotypic characterization based on PC-IGS (Barker et al., 1999; Bittencourt-Oliveira et al., 2001) is a result of culture-induced variation. BG1 $1_{0}$ and, to an even greater extent, AA are media with higher phosphorus concentrations than those found in the rivers, and this phosphorus enrichment could be responsible for the morphological variations and differential growth observed in our study. Fogg (1969) reported that even quite low concentrations of inorganic phosphate in artificial medium appear to be inhibitory for some genera, including
Gloeotrichia. A number of subsequent studies have indicated that the phosphorus status of the environment may be a particularly important factor in the growth of Rivulariaceae (Whitton, 1987).

All these results appeared to indicate that isolated strains BL1, BL2, E1, E7, MA8, MU15 and MU24 belong to the traditional Rivularia genus, and that strains E17, MU27, MU28, MU41 and TJ12 belong to the traditional Calothrix genus. However, it has been reported that some cyanobacteria possess two or three PC operons (Mazel et al., 1988; Dubbs \& Bryant, 1993; Golden, 1995) that are differentially expressed under different growth conditions. In this way, it is possible that our strains possess two or three operons, only one of which we have sequenced. This could give rise to misleading conclusions about the taxonomy.

\section{Molecular fingerprinting analysis - TGGE}

In order to evaluate the possibility suggested above, TGGE was carried out on the basis that PCR fragments of the same size but different sequence could be separated (Muyzer \& Smalla, 1998). For the TGGE analysis, we cloned specific sequences from strains or colonies (confirmed by sequencing) as markers corresponding to the three genotypes found. PCR products for each genotype were cloned in commercial vectors to ensure that, as only one fragment could be inserted in the vector, only one copy would be resolved on the gel. The high sequence variability among the three genotypes gave rise to three clearly separated bands that allowed us to characterize each genotype by its corresponding fingerprint (Fig. 4a, b). TGGE analysis of the isolated strains revealed only one band for each culture, and this band was consistent with the corresponding fingerprint (Fig. 4a).

For TGGE of natural Rivularia colonies, different samples from the rivers studied were examined morphologically beforehand (Fig. 1). Large colonies were collected from the Alharabe river. They had a very soft texture and consisted entirely of the $R$. biasolettiana type (Fig. 1a-c). We also 

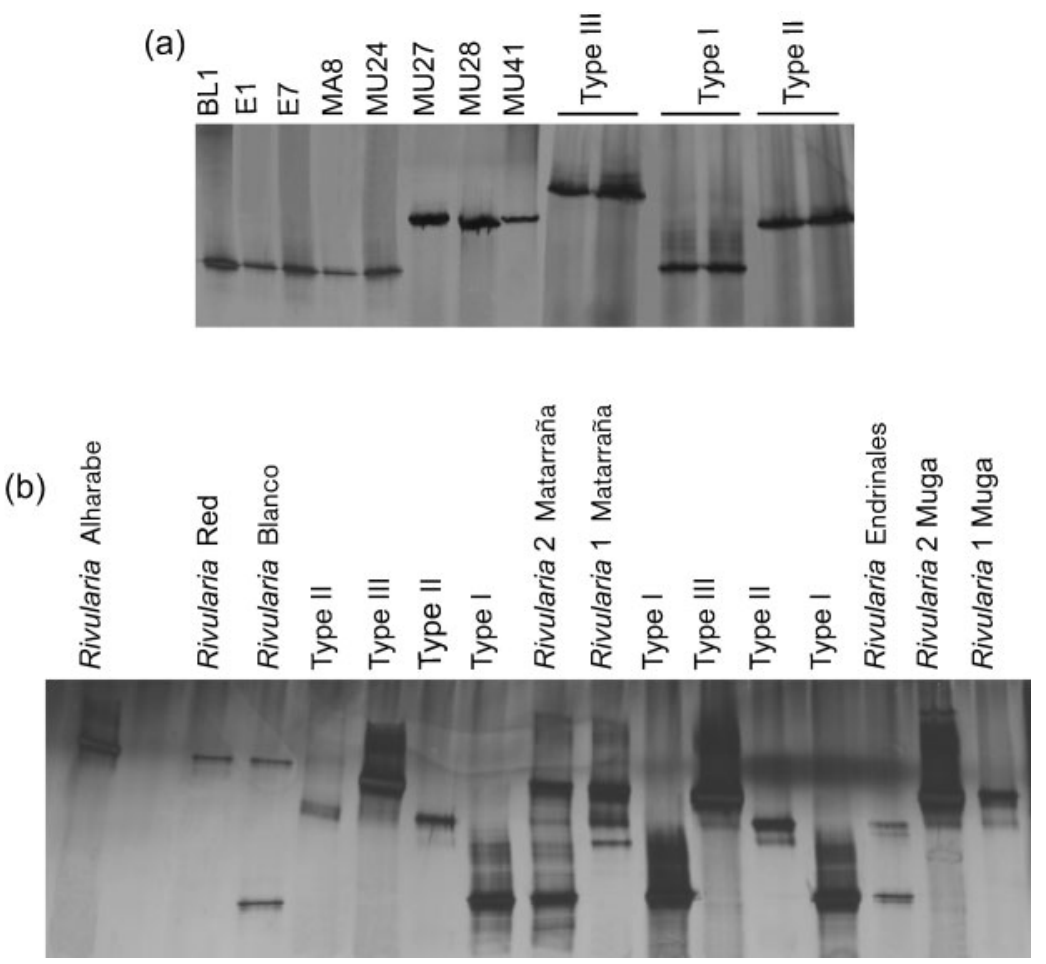

\begin{abstract}
Fig. 4. TGGE fingerprinting analysis of PCIGS PCR amplification of representative strains isolated from calcareous rivers (a) and field Rivularia colonies from the rivers of this study (b). Types I, II and III correspond to PCR products of cloned PC-IGS genotypes I, II and III, respectively, sequenced previously.
\end{abstract}

examined small hemispherical highly calcified colonies exhibiting obvious zonation (Fig. 1d-f) from Endrinales river, which were of the $R$. haematites type. However, some colonies had an ambiguous macroscopic and microscopic morphology, and some heterogeneity was found between trichomes of Rivularia, and even within trichomes of single colonies (Fig. 1i-o). Similar observations were described by Sinclair \& Whitton (1977), who found that three different morphological types of Rivulariaceae were released during incubation of pond Rivularia colonies and that the trichomes released from stream Rivularia colonies appeared to be of Calothrix.

This heterogeneity in colonial structure and trichome features is mirrored by a corresponding genetic diversity in TGGE analysis. In many samples, the colonies presented at least two distinct bands (Fig. 4b). Colonies collected from Red Sike and the Alharabe river, which were clearly of the $R$. biasolettiana type, presented a profile corresponding to genotype III. Colonies from the Endrinales river, which were typical $R$. haematites with very high calcification and with distinct zones inside, mainly displayed the band pattern corresponding to genotype I, although another band corresponding to genotype II could also be found. Colonies from the river Blanco presented two clear bands corresponding to genotypes I and III, similar to a colony from Matarraña river, but the other colony from the same river displayed a different profile with genotypes II and III. Two colonies from the river Muga shared a similar pattern that corresponded to genotype III, although a blurred band corresponding to genotype II could be observed (Fig. 4b). These results indicate that there may be genetic diversity even within a colony. In addition, we cannot rule out the possibility that other trichomes that are sometimes found in the colony, such as those for Calothrix (Fig. 1o), can be amplified by PCR of colonies. This would correspond to genotype II, which appears as blurred bands on gels (Fig. 4b).

\section{Phylogenetic analysis of the 16S rRNA gene and cpcBA-IGS sequences}

Similar results were found in the phylogenetic analysis of the 16S rRNA gene and PC operon sequences, whereby there was a distinct clustering of the three genotypes (Figs 5 and 6). To determine the phylogenetic position of the rivulariacean-type within the cyanobacterial radiation, the $16 \mathrm{~S}$ rRNA gene sequences obtained in this study in conjunction with the recently published sequences of Rivularia and other Calothrix from GenBank/EMBL/ DDBJ were compared with those of representatives of other genera of Nostocales, i.e. strains of the genera Tolypothrix, Nostoc, Nodularia, Cylindrospermopsis, Anabaena and Aphanizomenon, and also some distantly related cyanobacteria, such as strains of Chroococcidiopsis and Oscillatoria (Fig. 5). The rivulariacean-type sequences from this study and those from the database (except some Calothrix strains from the database) formed a cluster, separate from other cyanobacteria. This cluster was divided into three subclusters (A, B, C) in which genotypes II, I and III, respectively, were included. Clusters D, E, F and G contained, respectively, the genera Tolypothrix, Nostoc, Nodularia and Cylindrospermopsis. Anabaena and 


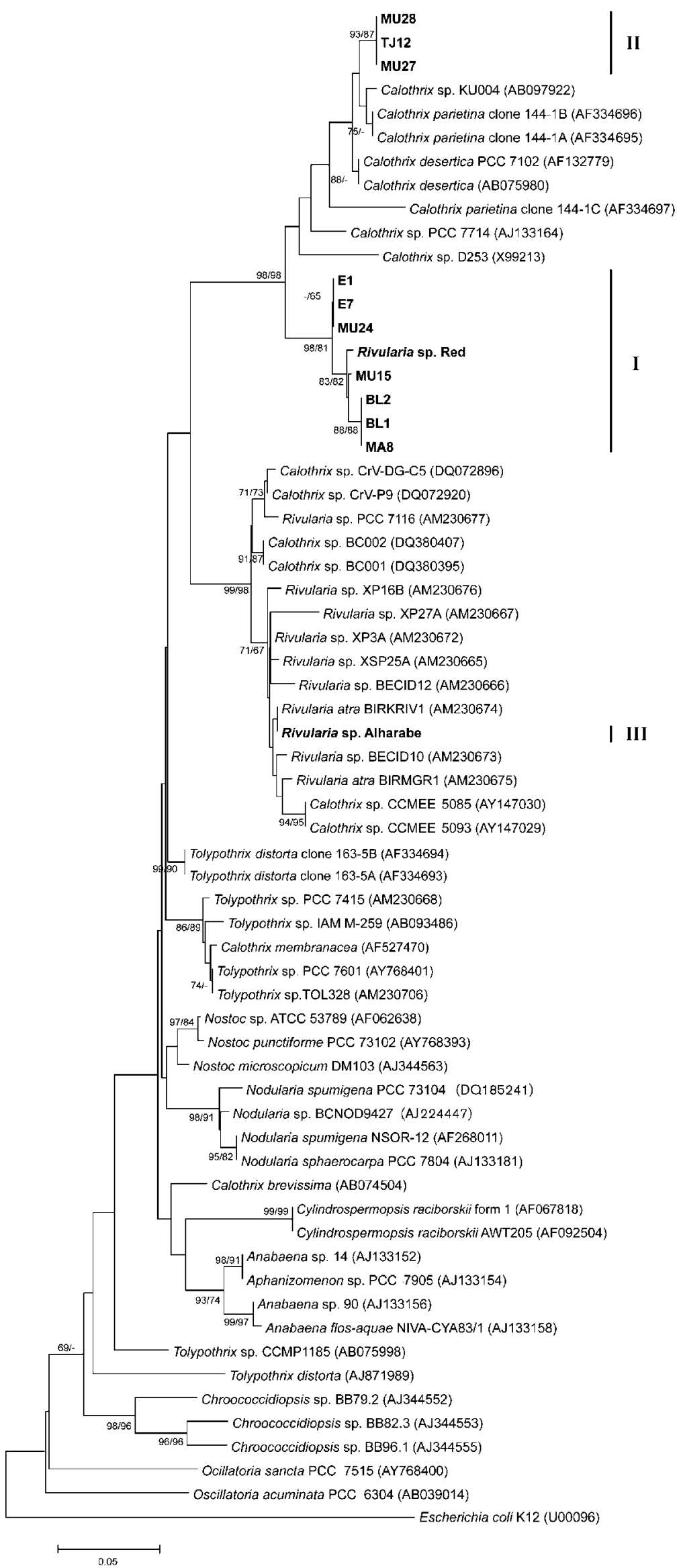

A

B

C

$\mathbf{D}$

$\mathbf{E}$

$\mathbf{F}$

G

H

Fig. 5. Neighbour-joining tree based on analysis of 16S rRNA genes showing the position of sequences obtained in this study (in bold). Numbers at nodes indicate bootstrap values greater than or equal to $65 \%$ for the $\mathrm{NJ}$ and MP analyses. Bar, 0.05 substitutions per nucleotide position. 
Aphanizomenon were grouped together in cluster $\mathrm{H}$, as found previously (Gugger \& Hoffmann, 2004; Rajaniemi et al., 2005).

Cluster A comprised the three identical sequences corresponding to genotype II from this study: two strains (MU27 and MU28) from the calcareous Muga river, and a strain (TJ12) from the siliceous Tejada stream, as well as other sequences of Calothrix from the database. These include two sequences of C. parietina, which showed $98.8 \%$ similarity to strains of genotype II, two strains of $C$. desertica (98\% similarity), Calothrix D253, originally classified as C. vigueri, and Calothrix PCC 7714, originally classified as C. marchica (96 and $95.6 \%$ similarity, respectively). A third clone of C. parietina was also included in the cluster but only had $93.5 \%$ similarity. DNA-DNA hybridization studies have been used to measure the degree of relatedness between organisms with high $16 \mathrm{~S}$ rRNA sequence similarity. Organisms with more than $70 \%$ DNA-DNA relatedness, which is the boundary value for recognition of a species (Wayne et al., 1987), often share more than $97 \%$ 16S rRNA gene similarity (Stackebrandt \& Goebel, 1994). Thus, when strains have $<97.5 \%$ similarity, the sequence data provide strong evidence that the strains represent separate species. However, it has been cautioned that, for strains with $>97.5 \%$ similarity, the molecular data may not be adequate to enable decisions to be made at the species level (Casamatta et al., 2005). Here, strains corresponding to genotype II had $98.8 \%$ similarity with $C$. parietina from the database, a species whose trichomes were frequently observed in microscopic analysis of our environmental samples, raising the possibility that genotype II corresponds to traditional C. parietina. DNA-DNA hybridiza- tion studies with $C$. parietina field populations could confirm species identity.

The highly supported cluster B contained sequences of strains, and a field Rivularia colony from Red Sike, from this study, corresponding to genotype I, which shared high $16 \mathrm{~S}$ rRNA gene sequence similarity (98.8-100\%). These findings suggest that cluster B represents a novel evolutionary branch which has not been characterized previously.

Cluster C comprised sequences of the genera Calothrix and Rivularia, and included the sequence of a $R$. biasolettiana type from the river Alharabe corresponding to genotype III of this study. Our Rivularia sequence showed a maximum sequence similarity of $99.9 \%$ (1384 bp) with Rivularia atra BIRKRIVI, but $99.2 \%$ with the other $R$. atra sequence (strain BIRMGR1), and a minimum of $97.3 \%$ similarity with Rivularia PCC 7116. The most divergent sequence in cluster C was that of Rivularia PCC 7116, ranging from 96 to $97.5 \%$ similarity.

In the cpcBA-IGS tree (Fig. 6), the nine sequences from natural Rivularia colonies and isolated strains from calcareous rivers corresponding to genotype I formed one cluster (eight of them are shown in Fig. 6), the five sequences from isolated strains from calcareous and siliceous rivers corresponding to genotype II formed a second cluster (three of them are shown in Fig. 6), and the four sequences from Rivularia colonies and a single isolated strain from calcareous rivers formed a third cluster (Fig. 6). Genotypes I and II clustered together in one group that was well supported by high bootstrap values. However genotype III was distant, consistent with the highest recorded percentage variability.

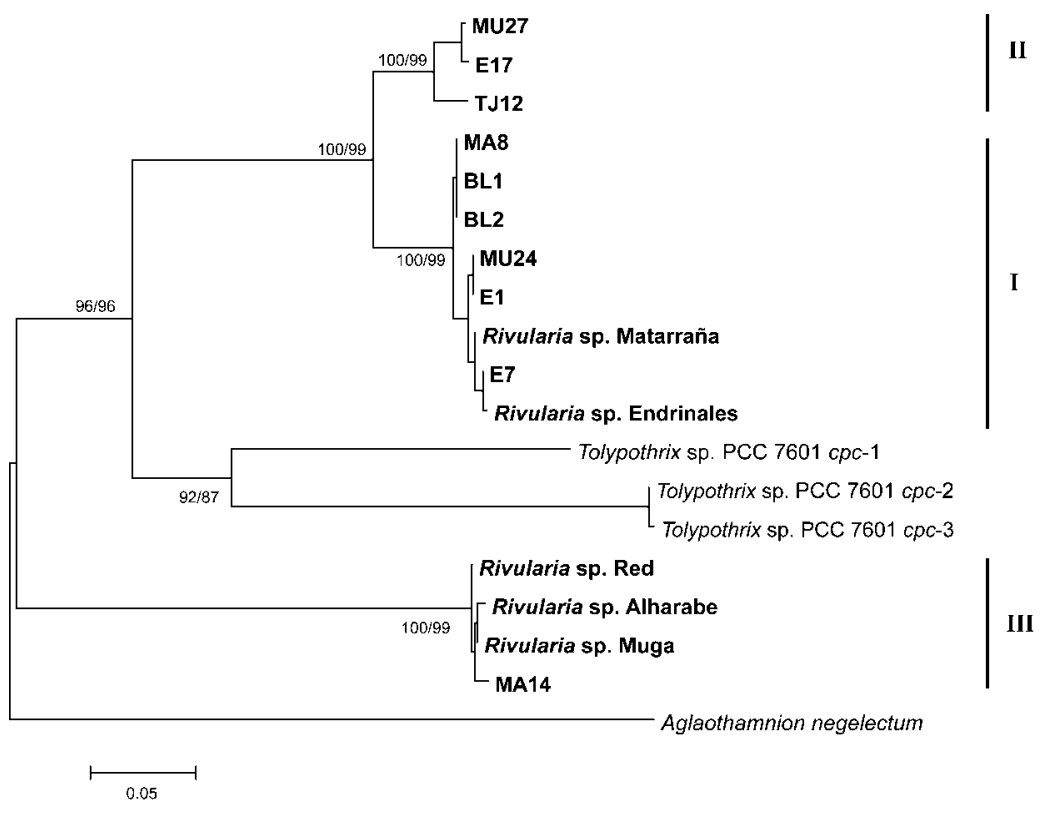

\footnotetext{
Fig. 6. Neighbour-joining tree based on analysis of sequences of the $c p c B A-I G S$ and flanking regions from 16 representative strains and field Rivularia colonies obtained during the present study (in bold) and three operons of Tolypothrix PCC 7601 as the only tapered strain from the database. Strains MU28 and MU41 had identical sequences to that of strain MU27, strain BL2 had an identical sequence to that of strain BL1, and strain MU15 had an identical sequence to that of strain MU24. Numbers at nodes indicate bootstrap values greater than or equal to $65 \%$ for the $\mathrm{NJ}$ and MP analyses. Bar, 0.05 substitutions per nucleotide position.
} 
Strain and field sample sequences corresponding to genotypes I and II from this study always clustered together, regardless of the method used to generate the tree and the gene analysed, suggesting that they were closely related. In contrast, PC operon analysis appeared to indicate that they belong to different genera. However, it has been pointed out that the phylogeny of the PC-IGS locus must be treated with care when attempting to deduce organismal phylogenies because the locus displays a complex evolutionary pattern (Manen \& Falquet, 2002; Janson \& Granéli, 2002). In our study, 16S rRNA gene and $c p c B A$-IGS data are clearly in agreement. Sequence similarity between genotypes I and II ranged from 93.3 to $94.3 \%$ in the $16 \mathrm{~S}$ rRNA gene phylogenetic analysis. A threshold of $95 \% 16 \mathrm{~S}$ rRNA gene sequence similarity has been suggested for the definition of a genus (Ludwig et al., 1998). Based on this definition, the evolutionary distances of this study confirmed the genotypes to represent separate genera, as the PC operon analysis had previously suggested. Taken together the morphological, phylogenetic and fingerprinting results, we can conclude that genotype I corresponds to the traditional genus Rivularia and genotype II to the traditional genus Calothrix.

The taxonomic status of the genus Calothrix has been discussed widely (Whitton, 1989; Komárek \& Anagnostidis, 1989; Wilmotte \& Herdman, 2001; Rippka et al., 2001b). Phylogenetic analysis of 16S rRNA gene sequences, and relationships between strains of the genus Calothrix deduced from DNA-DNA hybridization results (Lachance, 1981) demonstrated a high genetic diversity in this genus (Wilmotte \& Herdman, 2001; Rippka et al., 2001b). Recently, great sequence variability of the $16 \mathrm{~S}$ rRNA gene has been found among Calothrix strains from the Baltic Sea (Sihvonen et al., 2007), suggesting that they belong to at least five different genera. Hongmei et al. (2005) showed that a single morphotype of Calothrix in thermophilic cyanobacterial mats comprised five different $16 S$ rRNA genotypes. The tree topology obtained from phylogenetic analysis of cyanobacterial $16 \mathrm{~S}$ rRNA gene sequences in our study was in agreement with that of Sihvonen et al. (2007) and supported the idea that members of the genus Calothrix are polyphyletic and should be divided into several different genera.

Regarding the genus Rivularia, the sequences from this study and those from GenBank/EMBL/DDBJ showed great variability and were clearly not monophyletic. Morphological, sequencing and TGGE fingerprinting analysis showed that environmental Rivularia colonies were phenotypically and genotypically heterogeneous. It has been discussed whether $R$. haematites and $R$. biasolettiana are ecoforms of the same species or are different taxa (Kann, 1977). In contrast, Zehnder (1985), who worked with Rivularia cultures, concluded that $R$. biasolettiana, isolated from Lake Erken in Sweden, and $R$. haematites, isolated from a small creek in Switzerland, represented two distinct species. Whitton (2002) pointed out that $R$. haematites merges with $R$. biasolettiana, from which it differs only in the very high calcification and distinct zones.

Our results suggest that genotype I corresponds to traditional $R$. haematites and genotype III to traditional $R$. biasolettiana, and that sometimes clear traditional phenotypic types can been found that correspond to these genotypes. However, an ambiguous morphology can often be observed, which probably corresponds to the genetic diversity found within a single colony, as suggested previously by Whitton (1987). It has been pointed out that the colonies of some genera, such as Rivularia, are typically formed by the aggregation of a number of hormogonia (Whitton, 1987; Whitton \& Potts, 2000). Darley (1967), during a laboratory study of marine Rivulariaceae, found that hormogonia would only develop when a large quantity was inoculated simultaneously. In our study, morphological and genetic analysis suggested that representatives of both genotypes could be found in the same place. Thus, if the hormogonia involved in the aggregation are genetically homogeneous, the resulting colony will be dominated by one genotype, such as genotype III in the $R$. biasolettiana type, or genotype I in the $R$. haematites type. However, colonies formed by aggregation of genetically heterogeneous hormogonia will develop the genetic diversity found in this study. This also explains why phenotypically similar colonies collected at the same time from the same place had different genotypes (e.g. Rivularia colonies from Red Sike showing genotype III in the PC operon tree but genotype I in the 16S rRNA gene sequence analysis), and why both genotypes I and III could be found in a single colony in the fingerprinting analysis (e.g. colonies from the Blanco and Matarraña rivers), whereas others only showed one band, which corresponded to genotype III (e.g. another colony from Matarraña river). These results cast doubt on the validity of using colony morphology to identify and differentiate these species of Rivularia and suggest that classification clearly requires the use of distinction criteria other than morphology.

On the other hand, it must be emphasized that, although a similar and sometimes overlapping morphology has been observed in environmental Rivularia colonies, a clear genetic divergence has been demonstrated. Genotypes I and III were clearly distinct in the two phylogenetic trees. Only a 90.6$91.1 \% 16 \mathrm{~S}$ rRNA gene sequence similarity was found between genotypes I and III, indicating that the Rivularia sequences studied may actually represent two different genera. Rippka et al. (2001a, b, c) in the current taxonomic classification of Bergey's Manual of Systematic Bacteriology only include strains isolated from saline environments (intertidal zone, supralittoral shore, seawater aquarium) in the genus Rivularia, thus separating it from Calothrix by its higher salt requirement or tolerance. Sihvonen et al. (2007) found that, in their Rivularia isolates, only the truly marine Rivularia PCC 7116 was able to grow in elevated salt concentrations, but that the Baltic Sea Rivularia strains did not require elevated salt as the brackish water of the Gulf of Finland, where most of the strains were isolated, has a 
salinity of about $5 \%$. Calothrix CCMEE 5085 and Calothrix CCMEE 5093, which were also included in cluster $\mathrm{C}$ along with all Rivularia sequences, were isolated from a siliceous substrate of shallow, tepid $\left(<35{ }^{\circ} \mathrm{C}\right)$ hot spring effluents in Yellowstone National Park with a salinity of about $1 \%$ (Dillon \& Castenholz, 2003). Our sequence in this cluster corresponds to a Rivularia from freshwater although, as it only occurs in calcareous rivers, elevated concentrations of $\mathrm{Ca}^{2+}$ could be required for its growth. It is also possible that they are euryhaline since a tolerance to desiccation has been observed. Therefore, if we maintain genotype III as Rivularia, a new genus should be invoked for the Rivularia representatives of genotype I in cluster B of our study.

These results suggest that the cyanobacteria classified in the traditional genus Rivularia diversified through evolution. A possible explanation is that the Rivularia-like morphology represents an ancestral morphology type from which other morphologies, such as Calothrix-like, have evolved. Another possibility is that filament tapering may have evolved more than once during the diversification of heterocyst-forming cyanobacteria, as suggested previously (Sihvonen et al., 2007).

In conclusion, the genera Rivularia and Calothrix showed great heterogeneity. Rivulariacean-type isolates from this study showed considerable genetic divergence but overlapping morphologies. However, the use of a culture medium with a low level of nutrients, more closely approximating the characteristics of the rivers with Rivularia colonies, allowed us to observe Rivularia-like characteristics under laboratory conditions. All the sequences of environmental Rivularia colonies and rivulariacean-type isolates analysed fell into one of three distinct genotypes, denominated types I, II and III. On the basis of $16 \mathrm{~S}$ rRNA gene and PC genetic analysis, these three genotypes were polyphyletic and, according to the genetic data, may actually represent three different genera. On the other hand, morphological and fingerprinting analysis showed that trichomes within single Rivularia colonies could be phenotypically and genetically different, which makes the taxonomic assessment of Rivularia even more difficult. Representatives of the genera Rivularia and Calothrix in our study and in GenBank/ EMBL/DDBJ were intermixed in phylogenetic inferences and showed great genetic divergence. This supports the hypothesis that the traditional family of Rivulariaceae is one of the most diverse cyanobacterial lineages, with the implication that a revision of their taxonomy is needed.

\section{ACKNOWLEDGEMENTS}

We thank two anonymous reviewers for helpful comments and valuable suggestions. We especially thank Brian A. Whitton for his critical reading of the manuscript, useful comments throughout this research and for providing us with Rivularia colonies from Red Sike. We are grateful to Marina Aboal and M. Angeles Puig for providing us with Rivularia colonies from the Alharabe, Endrinales, Matarraña and Muga rivers, and to Marina Aboal for long taxonomic discussions. Special thanks are due to Francisco Leganés and Marta Martín for their helpful comments. We also thank Philip Mason for correcting the English of the text and Antonio Quesada for helpful suggestions on the manuscript. This work was supported by a grant (CGL2004-03478/BOS) and a fellowship (to E. B.) from the Ministerio de Educación y Ciencia, Spain, and was also funded by the Comunidad Autónoma de Madrid (GR/AMB/0084/2004 and S0505/AMB/0321).

\section{REFERENCES}

Aboal, M., Puig, M. A., Mateo, P. \& Perona, E. (2002). Implications of cyanophyte toxicity on biological monitoring of calcareous streams in north-east Spain. J Appl Phycol 14, 49-56.

Aboal, M., Puig, M. A. \& Asencio, A. D. (2005). Production of microcystins in calcareous Mediterranean streams: the Alharabe River, Segura River basin in south-east Spain. J Appl Phycol 17, 231-243.

Allen, M. B. \& Arnon, D. I. (1955). Studies on nitrogen-fixing bluegreen algae. I. Growth and nitrogen fixation by Anabaena cylindrica Lemm. Plant Physiol 30, 366-372.

Barker, G. L. A., Hayes, P. K., O'Mahony, S. L., Vacharapiyasophon, P. \& Walsby, A. E. (1999). A molecular and phenotypic analysis of Nodularia (cyanobacteria) from the Baltic Sea. J Phycol 35, 931-937.

Barker, G. L. A., Konopka, A., Handley, B. A. \& Hayes, P. K. (2000). Genetic variation in Aphanizomenon (cyanobacteria) colonies from the Baltic Sea and North America. J Phycol 36, 947-950.

Bittencourt-Oliveira, M. C., Cabral de Oliveira, M. \& Bolch, C. J. S. (2001). Genetic variability of Brazilian strains of the Microcystis aeruginosa complex (Cyanobacteria/Cyanophyceae) using the phycocyanin intergenic spacer and flanking regions ( $c p c B A) . J$ Phycol 37, 810-818.

Bolch, C. J. S., Blackburn, S. I., Neilan, B. A. \& Grewe, P. M. (1996). Genetic characterization of strains of cyanobacteria using PCR-RFLP of the $c p c B A$ intergenic spacer and flanking regions. J Phycol 32, 445-451.

Bolch, C. J. S., Orr, P. T., Jones, G. J. \& Blackburn, S. I. (1999). Genetic, morphological, and toxicological variation among globally distributed strains of Nodularia (cyanobacteria). J Phycol 35, 339-355.

Casamatta, D. A., Johansen, J. R., Vis, M. L. \& Broadwater, S. T. (2005). Molecular and morphological characterization of ten polar and near-polar strains within the Oscillatoriales (cyanobacteria). J Phycol 41, 421-438.

Castenholz, R. W. (2001). Phylum BX. Cyanobacteria. Oxygenic photosynthetic bacteria. In Bergey's Manual of Systematic Bacteriology, 2nd edn, vol. 1, pp. 473-487. Edited by D. R. Boone, R. W. Castenholz \& G. M. Garrity. New York: Springer.

Castenholz, R. W. \& Norris, T. B. (2005). Revisionary concepts of species in the Cyanobacteria and their applications. Arch Hydrobiol Algol Stud 117, 53-69.

Chu, S. P. (1942). The influence of the mineral composition of the medium on the growth of planktonic algae. Part 1 . Methods and culture media. J Ecol 30, 284-325.

Darley, J. (1967). Sur quelques résultats de la culture en laboratoire de deux espèces de Calothrix Agardh (Myxophycées-Rivulariacées). $C R$ Acad Sci Ser D 264, 1013-1015.

Dillon, J. G. \& Castenholz, R. W. (2003). The synthesis of the UVscreening pigment, scytonemin, and photosynthetic performance in isolates from closely related natural populations of cyanobacteria (Calothrix sp.). Environ Microbiol 5, 484-491.

Doyle, J. J. \& Doyle, J. L. (1990). Isolation of plant DNA from fresh tissue. Focus 12, 13-15. 
Dubbs, J. M. \& Bryant, D. A. (1993). Organization and transcription of the genes encoding two differentially expressed phycocyanins in the cyanobacterium Pseudanabaena sp PCC 7409. Photosynth Res 36, 169-183.

Felsenstein, J. (1985). Confidence limits on phylogenies: an approach using the bootstrap. Evolution 39, 783-791.

Fogg, G. E. (1969). Physiology of an algal nuisance. Proc R Soc Lond B Biol Sci 173, 175-189.

Fox, G. E., Wisotzkey, J. D. \& Jurtshuk, P., Jr (1992). How close is close: $16 \mathrm{~S}$ rRNA sequence identity may not be sufficient to guarantee species identity. Int J Syst Bacteriol 42, 166-170.

Garcia-Pichel, F., Lopez-Cortes, A. \& Nübel, U. (2001). Phylogenetic and morphological diversity of cyanobacteria in soil desert crusts from the Colorado Plateau. Appl Environ Microbiol 67, 1902-1910.

Geitler, L. (1932). Cyanophyceae. In Kryptogamenflora von Deutschland, Oesterreich und der Schweiz, vol. 14. Edited by L. Rabenhorst. Leipzig: Akademische Verlagsgesellschaft.

Golden, S. S. (1995). Light-responsive gene expression in cyanobacteria. J Bacteriol 177, 1651-1654.

Golubic, S. (1979). Cyanobacteria (blue-green algae) under the bacteriological code? An ecological objection. Taxon 28, 387-389.

Gugger, M. F. \& Hoffmann, L. (2004). Polyphyly of the true branching cyanobacteria (Stigonematales). Int J Syst Evol Microbiol 54, 349-357.

Hongmei, J., Aitchison, J. C., Lacap, D. C., Peerapornpisal, Y., Sompong, U. \& Pointing, S. B. (2005). Community phylogenetic analysis of moderately thermophilic cyanobacterial mats from China, the Philippines and Thailand. Extremophiles 9, 325-332.

Janson, S. \& Granéli, E. (2002). Phylogenetic analyses of nitrogenfixing cyanobacteria from the Baltic Sea reveal sequence anomalies in the phycocyanin operon. Int J Syst Evol Microbiol 52, 1397-1404.

Kann, E. (1977). Zur Taxonomie von Rivularia. In Symposium über Fragen der Cyanophytentaxonomie in Lednice (CSSR), 29. Jul bis 8. August 1976, Venhandlungsbericht - Z. Schweiz. Hydrol 39, 134-136.

Komárek, J. \& Anagnostidis, K. (1989). Modern approach to the classification system of Cyanophytes 4 - Nostocales. Arch Hydrobiol Suppl 82, 247-345.

Komárek, J. \& Anagnostidis, K. (1999). Cyanoprokariota: Chroococcales. In Süßwasserflora von Mitteleuropa, 1st edn, vol. 19/ 1. Edited by G. Fischer. Germany: Jena Stuttgart Lübeck Ulm.

Komárek, J. \& Kaštovský, J. (2003). Coincidences of structural and molecular characters in evolutionary lines of cyanobacteria. Arch Hydrobiol Suppl 148, 305-325.

Kumar, S., Tamura, K. \& Nei, M. (2004). MEGA3: integrated software for Molecular Evolutionary Genetics Analysis and sequence alignment. Brief Bioinform 5, 150-163.

Lachance, M.-A. (1981). Genetic relatedness of heterocystous cyanobacteria by deoxyribonucleic acid-deoxyribonucleic acid reassociation. Int J Syst Bacteriol 31, 139-147.

Ludwig, W., Strunk, O., Klugbauer, S., Klugbauer, N., Weizenegger, M., Neumaier, J., Bachleither, M. \& Schleifer, K. H. (1998). Bacterial phylogeny based on comparative sequence analysis. Electrophoresis 19, 554-568.

Manen, J.-F. \& Falquet, J. (2002). The $c p c B-c p c A$ locus as a tool for the genetic characterization of the genus Arthrospira (Cyanobacteria): evidence for horizontal transfer. Int J Syst Evol Microbiol 52, 861-867.

Mateo, P., Bonilla, I., Fernández-Valiente, E. \& Sánchez-Maeso, E. (1986). Essentiality of boron for dinitrogen fixation in Anabaena PCC 7119. Plant Physiol 81, 430-433.

Mazel, D., Houmard, J. \& Tandeau de Marsac, N. (1988). A multigene family in Calothrix sp. PCC 7601 encodes phycocyanin, the major component of the cyanobacterial light-harvesting antenna. Mol Gen Genet 211, 296-304.

Moore, L. R., Rocap, G. \& Chisholm, S. W. (1998). Physiology and molecular phylogeny of coexisting Prochlorococcus ecotypes. Nature 393, 464-467.

Muyzer, G. \& Smalla, K. (1998). Application of denaturing gradient gel electrophoresis (DGGE) and temperature gradient gel electrophoresis (TGEE) in microbial ecology. Antonie van Leeuwenhoek 73, 127-141.

Neilan, B. A., Jacobs, D. \& Goodman, A. E. (1995). Genetic diversity and phylogeny of toxic cyanobacteria determined by DNA polymorphisms within the phycocyanin locus. Appl Environ Microbiol 61, 3875-3883.

Nicholas, K. B. \& Nicholas, H. B. L. (1997). GeneDoc: a tool for editing and annotation multiple sequence alignments. Distributed by the authors (http://www.psc.edu/biomed/genedoc).

Nübel, U., Garcia-Pichel, F. \& Muyzer, G. (1997). PCR primers to amplify 16S rRNA genes from cyanobacteria. Appl Environ Microbiol 63, 3327-3332.

Pomati, F., Sacchi, S., Rossetti, C., Giovannardi, S., Onodera, H., Oshima, Y. \& Neilan, B. A. (2000). The freshwater cyanobacterium Planktothrix sp FP1: molecular identification and detection of paralytic shellfish poisoning toxins. J Phycol 36, 553-562.

Rajaniemi, P., Hrouzek, P., Kaštovská, K., Willame, R., Rantala, A., Hoffmann, L., Komárek, J. \& Sivonen, K. (2005). Phylogenetic and morphological evaluation of the genera Anabaena, Aphanizomenon, Trichormus and Nostoc (Nostocales, Cyanobacteria). Int J Syst Evol Microbiol 55, 11-26.

Rippka, R., Deruelles, J., Waterbury, J. B., Herdman, M. \& Stanier, R. Y. (1979). Generic assignments, strain histories, and properties of pure cultures of cyanobacteria. J Gen Microbiol 111, 1-61.

Rippka, R., Castenholz, R. W. \& Herdman, M. (2001a). Subsection IV. (Formerly Nostocales Castenholz 1989b sensu Rippka, Deruelles, Waterbury, Herdman and Stanier 1979). In Bergey's Manual of Systematic Bacteriology, 2nd edn, vol. 1, pp. 562-566. Edited by D. R. Boone, R. W. Castenholz \& G. M. Garrity. New York: Springer.

Rippka, R., Castenholz, R. W. \& Herdman, M. (2001b). Form-genus I. Calothrix Agardh 1824. In Bergey's Manual of Systematic Bacteriology, 2nd edn, vol. 1, pp. 582-585. Edited by D. R. Boone, R. W. Castenholz \& G. M. Garrity. New York: Springer.

Rippka, R., Castenholz, R. W. \& Herdman, M. (2001c). Form-genus II. Rivularia Agardh 1824. In Bergey's Manual of Systematic Bacteriology, 2nd edn, vol. 1, pp. 586-587. Edited by D. R. Boone, R. W. Castenholz \& G. M. Garrity. New York: Springer.

Robertson, B. R., Tezuka, N. \& Watanabe, M. M. (2001). Phylogenetic analyses of Synechococcus strains (cyanobacteria) using sequences of $16 \mathrm{~S}$ rDNA and part of the phycocyanin operon reveal multiple evolutionary lines and reflect phycobilin content. Int J Syst Evol Microbiol 51, 861-871.

Rodríguez, V., Aguirre de Cárcer, D., Loza, V., Perona, E. \& Mateo, P. (2007). A molecular fingerprint technique to detect pollution-related changes in river cyanobacterial diversity. J Environ Qual 36, 464-468.

Saitou, N. \& Nei, M. (1987). The neighbor-joining method: a new method for reconstructing phylogenetic trees. Mol Biol Evol 4, 406-425.

Sanguinetti, C. J., Neto, E. D. \& Simpson, A. J. G. (1994). Rapid silver staining and recovery of PCR products separated on polyacrylamide gels. Biotechniques 17, 914-918.

Sheffield, V. C., Cox, D. R., Lerman, L. S. \& Myers, R. M. (1989). Attachment of a 40-base-pair G+C-rich sequence (GC-clamp) to genomic DNA fragments by the polymerase chain-reaction results in improved detection of single-base changes. Proc Natl Acad Sci U S A 86, 232-236. 
Sihvonen, L. M., Lyra, C., Fewer, D. P., Rajaniemi-Wacklin, P., Lehtimäki, J. M., Wahlsten, M. \& Sivonen, K. (2007). Strains of the cyanobacterial genera Calothrix and Rivularia isolated from the Baltic Sea display cryptic diversity and are distantly related to Gloeotrichia and Tolypothrix. FEMS Microbiol Ecol 61, 74-84.

Sinclair, C. \& Whitton, B. A. (1977). Influence of nutrient deficiency on hair formation in Rivulariaceae. Br Phycol J 12, 297-313.

Stackebrandt, E. \& Goebel, B. M. (1994). Taxonomic note: a place for DNA-DNA reassociation and $16 \mathrm{~S}$ rRNA sequence analysis in the present species definition in bacteriology. Int J Syst Bacteriol 44, 846-849.

Tajima, F. \& Nei, M. (1984). Estimation of evolutionary distance between nucleotide sequences. Mol Biol Evol 1, 269-285.

Taton, A., Grubisic, S., Ertz, D., Hodgson, D. A., Piccardi, R., Biondi, N., Tredici, M. R., Mainini, M., Losi, D. \& other authors (2006). Polyphasic study of Antarctic cyanobacterial strains. J Phycol 42, 1257-1270.

Teneva, I., Dzhambazov, B., Mladenov, R. \& Schirmer, K. (2005). Molecular and phylogenetic characterization of Phormidium species (Cyanoprokaryota) using cpcB-IGS-cpcA locus. J Phycol 41, 188-194.

Thompson, J. D., Gibson, T. J., Plewniak, F., Jeanmougin, F. \& Higgins, D. G. (1997). The CLUSTAL_X windows interface: flexible strategies for multiple sequence alignment aided by quality analysis tools. Nucleic Acids Res 25, 4876-4882.

Wayne, L. G., Brenner, D. J., Colwell, R. R., Grimont, P. A. D., Kandler, O., Krichevsky, M. I., Moore, L. H., Moore, W. E. C., Murray, R. G. E. \& other authors (1987). International Committee on Systematic Bacteriology. Report of the ad hoc committee on reconciliation of approaches to bacterial systematics. Int J Syst Bacteriol 37, 463-464.

Whitton, B. A. (1987). The biology of Rivulariaceae. In The Cyanobacteria, pp. 513-534. Edited by P. Fay \& C. Van Baalen. Amsterdam: Elsevier.
Whitton, B. A. (1989). Genus I. Calothrix Agardh 1824. In Bergey's Manual of Systematic Bacteriology, 1st edn, vol. 3, pp. 1791-1794. Edited by J. T. Staley, M. P. Bryant, N. Pfennig \& J. G. Holt. Baltimore: Williams \& Wilkins.

Whitton, B. A. (1992). Diversity, ecology and taxonomy of the cyanobacteria. In Photosynthetic Prokaryotes, vol. 6, pp. 1-51. Edited by N. H. Mann \& N. G. Carr. Biotechnology Handbooks. London: Plenum.

Whitton, B. A. (2002). Phylum Cyanophyta (Cyanobacteria). In The Freshwater Algal Flora of the British Isles. An Identification Guide to Freshwater and Terrestrial Algae, 1st edn, pp. 25-122. Edited by D. M. John, B. A. Whitton \& A. J. Brook. Cambridge: Cambridge University Press.

Whitton, B. A. \& Potts, M. (2000). Introduction of cyanobacteria. In The Ecology of Cyanobacteria. Their Diversity in Time and Space, pp. 1-10. Edited by B. A. Whitton \& M. Potts. Dordrecht: Kluwer.

Wilmotte, A. (1994). Molecular evolution and taxonomy of the cyanobacteria. In The Molecular Biology of Cyanobacteria, pp. 1-25. Edited by D. A. Bryant. Dordrecht: Kluwer Academic.

Wilmotte, A. \& Herdman, M. (2001). Phylogenetic relationships among the cyanobacteria based on 16S rRNA sequences. In Bergey's Manual of Systematic Bacteriology, 2nd edn, vol. 1, pp. 487-493. Edited by D. R. Boone \& R. W. Castenholz. New York: Springer.

Wilmotte, A., Demonceau, C., Goffart, A., Hecq, J. H., Demoulin, V. \& Crossley, A. C. (2002). Molecular and pigment studies of the picophytoplankton in a region of Southern Ocean $\left(42-54^{\circ}\right.$ S, 141$144^{\circ}$ E) in March 1998. Deep Sea Res Part II Top Stud Oceanogr 49, 3351-3363.

Zehnder, A. (1985). Isolation and cultivation of large cyanophytes for taxonomic purposes. Arch Hydrobiol Algol Stud 71, 281-289. 